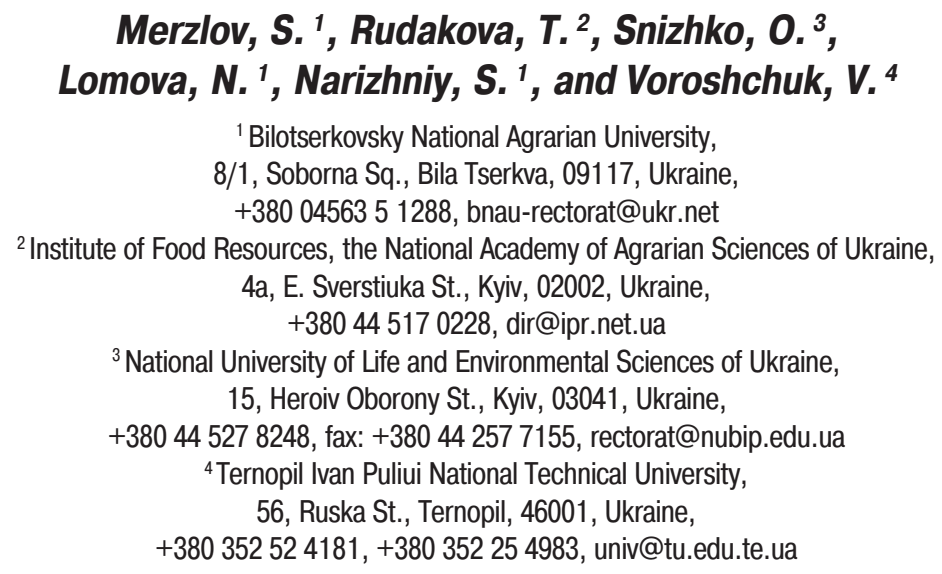

\title{
MANAGING QUALITY AND SAFETY DURING THE PRODUCTION OF YOGHURT WITH HONEY PRODUCTS
}

Introduction. One of the innovative approaches to developing food quality and safety programs today is a system based on the principles of HACCP (Hazard Analysis Critical Control Points). The system enables to prevent danger in the early stages of food production.

Problem Statement. In Ukraine, it is necessary to carry out a special monitoring of the quality and safety of dairy products due to a poor quality of raw materials and significant difficulties in tracing its use in the processing, which, together with the lack of refrigerated logistics and storage, significantly shorten the shelf life of Ukrainian dairy products as compared with the European ones.

Purpose. The use of HACCP principles for developing new types of dairy products, in particular, yogurt with honey products.

Materials and Methods. Dairy, biotechnological and non-dairy raw materials, packing material, stages of the technological process.

Results. All possible hazard factors that may exist in raw materials, packing materials or during the use of any technological operation associated with the product haves been identified. The analysis of risks for each potentially dangerous factor during the production of yogurt with honey products has been carried out and a list of potential dangers based on the risk chart has been compiled. It has been established that the biological potentially dangerous factors include coliforms, pathogenic microbes, mold, and yeast; the chemical ones are toxic elements, radionuclides, mycotoxins, and antibiotics; the physical ones include impurities coming from raw materials, with water, from technological equipment and packing materials. Six critical control points have been determined: the acceptance of dairy and non-dairy raw materials; cooling and reservation of milk; pasteurization; fermentation; and packing.

Conclusions. The technological chart for making yogurt with honey products by a reservoir method using the HACCP elements has been developed and the indicators of quality and safety of the finished product have been determined.

Keywords: yoghurt, honey products, quality, safety, technology, risk, hazard factor, and critical control points.

The development of society leads to an increase in the level of risk to the existence of the human-

(C) MERZLOV, S., RUDAKOVA, T., SNIZHKO, O., LOMOVA, N., NARIZHNIY, S., and VOROSHCHUK, V., 2018 kind. The determinants are risks associated with food products, drinking water, natural and manmade environments. The safety of drinking water and food products is the main factor of health and 
longevity of human being. The quality and safety of food products are currently determined not only by their attractiveness for domestic consumers, but also by their competitiveness in world markets.

There are many dangers associated with foodstuffs that can be harmful to human health. Every year, millions people around the world suffer from food poisoning. Uncontrolled use of various nutritional additives, microbiological hazards, environment pollution, agrochemicals and other abuses in the production of food products significantly reduce the level of food safety. As awareness of the consequences of food hazards for human health as well as the importance and rapid growth of the global food market and the consumer demand for safe food products increase, analyzing the risks associated with foodstuffs gets more and more relevant [1-3].

Pursuant to the Law of Ukraine on the Basic Principles and Requirements for the Safety and Quality of Food Products, food safety is the condition of food product that results from activities related to its manufacture and circulation, which are carried out in compliance with the requirements established by sanitary measures and/or technical regulations, and ensures the confidence that this food product does not harm the health of the person (consumer) provided it is consumed as intended [4]. The modern food industry is characterized by the use of diverse raw materials, food additives, packing materials, which causes the emergence of both positive and negative consequences for the human health. In this situation, the most logical step for manufacturing highquality products is to harmonize the requirements for product safety through the use of the generally accepted Hazard Analysis Critical Control Points [5].

HACCP is internationally recognized preventive approach aiming, firstly, at predicting and preventing biological, physical, and chemical hazards and, further, at testing the final product. It is a system for assessing the hazards of raw food materials, processes, and finished products. This system pays particular attention to the process control at the earliest stages of the product manufacture scheme using control of operations and (or) methods and continuous monitoring at critical control points $[5,6]$. This system can apply to a wide range of simple and complex operations throughout the foodstuff production and sale chain. In addition, it has the following advantages over other quality management systems:

+ prohibit the production and distribution of hazardous food products;

+ can apply to all parts of the food chain;

+ designed specifically for controlling food and raw food materials;

+ uses a precautionary approach;

+ clearly divides the personnel responsibility for the safety of products;

+ reliably protects the manufacturer reputation [7].

The Codex Alimentarius Commission defines the hazard as biological, chemical or physical factor in food product or the condition of food product with a potential adverse effect on the human health. Physical hazards (for example, solid particles in buckwheat or beans, bones in meat, etc.) are most easily detected; the effect of chemical and biological hazards is much more complicated because of the lack of research data to support various theories and the complexity of interactions between biochemical processes in the human body. The human body reaction to the disease or the harm-causing factors depends on many different interconnected factors. In addition, the effects on health in various people may be severe, moderate or absent [8].

In the domestic market, there is a very diverse range of fermented milk drinks, but the majority of them contains synthetic or modified ingredients. Unnatural fillers, stabilizers, thickeners, excess sugar, etc. greatly reduce the nutritional and biological value of natural fermented dairy products. In addition, the demand for "premium" organic dairy products made exclusively of natural ingredients that have not underwent any transformation is constantly growing. 
The Criteria for Assessment of Hazard Factors

\begin{tabular}{|c|c|c|}
\hline \multirow{2}{*}{ Score } & \multicolumn{2}{|r|}{ Criteria } \\
\hline & Probability & Consequences for the human health \\
\hline 1 & Very low & mild (does not lead to disablement) \\
\hline 2 & Low & $\begin{array}{l}\text { moderate (disablement during seve- } \\
\text { ral days, no further manifestations } \\
\text { of adverse effects) }\end{array}$ \\
\hline 3 & Considerable & $\begin{array}{l}\text { Severe (long-term disablement, } 3^{\text {rd }} \\
\text { group disability) }\end{array}$ \\
\hline 4 & High & $\begin{array}{l}\text { Critical ( } 1^{\text {st }} \text { or } 2^{\text {nd }} \text { group disability, } \\
\text { lethal effect) }\end{array}$ \\
\hline
\end{tabular}

Therefore, the creation of natural, high-quality, and safe fermented milk products that have a targeted effect on the consumer's body and high consumer properties is a relevant task. It has been achieved by developing an innovative technology for the manufacture of fermented milk product based on raw dairy materials and honey products as extremely rich source of essential nutrients. The technology is a set of operations to be performed in a clearly defined sequence, which ensures a high quality of the finished product [9].

The use of the HACCP system in the production of food products has been discussed in the works of Yu. P. Belov [10], T. M. Dymanya, T.G. Mazura [11], and O. M. Yakubchak [12]. In the scholarly research literature, there are publications on the analysis of potential hazards during the production of dairy products [13-16]. However, for manufacturing new safe food products, appropriate management programs should be developed in order to assure their quality and safety.

The aim of this research is to apply innovative approaches to the development of quality and safety management programs for manufacturing yogurt with honey products.

The objects of research are as follows: raw milk (unskimmed cow milk) in accordance with DSTU 3662-97, the biotechnological material is a bacterial preparation according to TU U 15.824367290-013: 2006; the non-dairy materials are beekeeping (honey) products (pollen pellet in ac- cordance with DSTU 3127-95, cis-Carpathian natural honey according to DSTU 4497:2005, royal jelly according to DSTU 4666:2006), sugar powder according to DSTU 2213-93; the finished product is yoghurt with honey products according to TU U 15.5-00493706-002:2009; the packing material is polystyrene cups; and the stages of the technological process.

To identify the risk factors in the technology for manufacturing yogurt with honey products the decision-tree scheme has been used [17, 67].

The probability for each hazardous factor has been assessed using the algorithm shown in Fig. 1 [18], which is based on the combination of practice, epidemiological data and information from scholarly research literature.

The probability of hazard factors and the danger level are scored in points as given in Table 1 [18].

The risk analysis for each potentially hazardous factor has been made taking into account the probability of each factor and the severity of the consequences based on the diagram $[17,80]$.

In order to objectively assess the requirements for establishing critical control points (CCP) to control the identified hazard factors for each type of raw material used, within the framework of specific operation of the technological process, the decision-tree scheme has been used [17, 95]. It provides for sequential answers to the systematized list of six questions.

The analysis of the hazards is a decisive principle of the HACCP system. The hazard factors are processed in the two stages: the identification and the analysis. In order to analyze and to properly identify all potential hazards, it is necessary to have profound technical and scientific knowledge in various spheres of food production [5].

Within the HACCP system, only such hazards are considered, the prevention, elimination or reduction of which to acceptable levels are essential for the production of safe food products. The factors that are unlikely to occur or have a negligible effect are not considered within the framework 


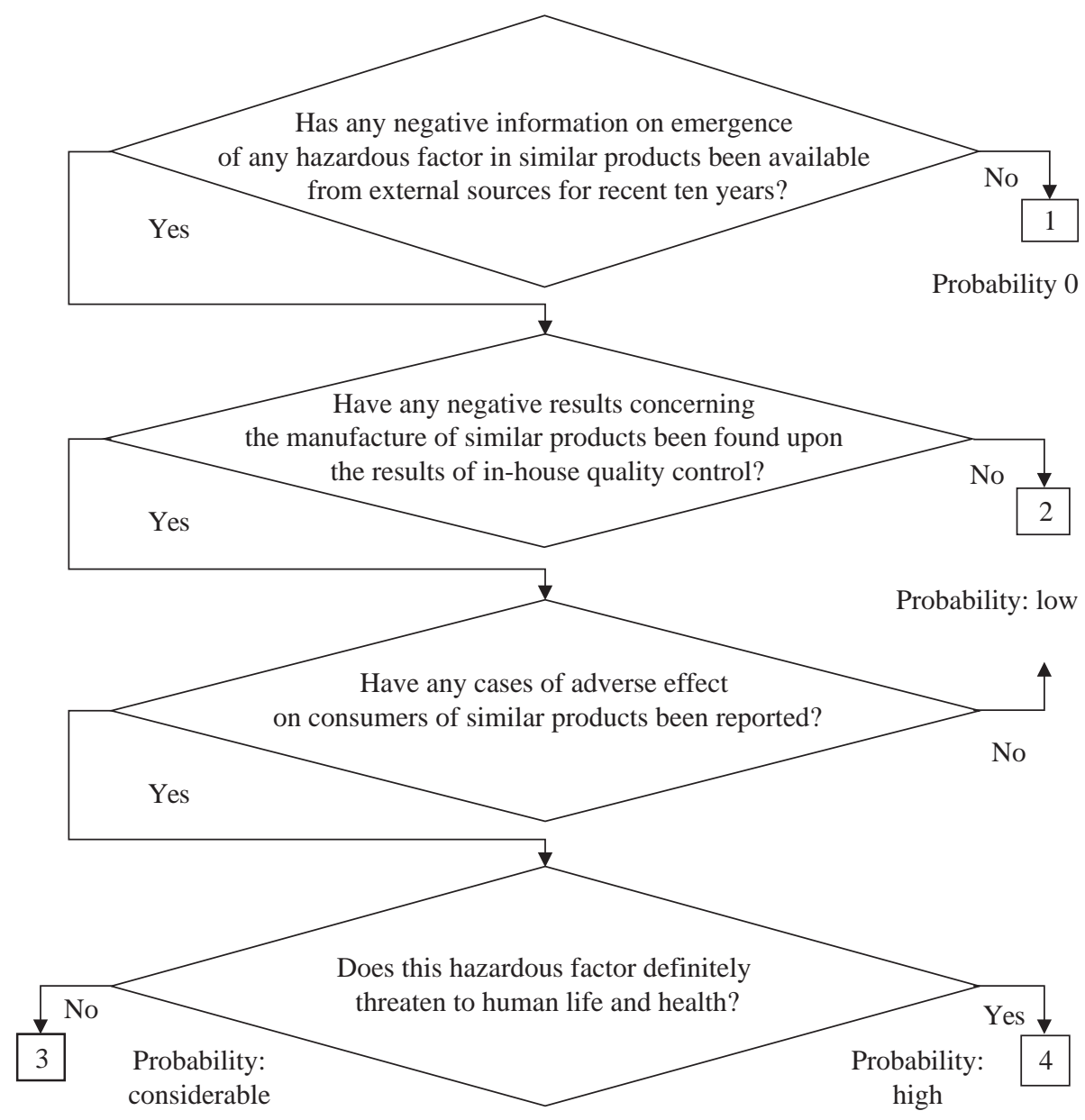

Fig. 1. Algorithm for assessment of hazard factor probability

of the HACCP system, but can be taken into account in terms of Good Manufacturing Practices (GMP/GHP) or general sanitary and hygiene rules for specific branch of food industry [17].

In order to identify all possible hazards that may exist in raw materials, packing materials or in the course of any technological operation related to the manufacture of product, it is necessary to make a complete description of the food product, including all the ingredients, processing methods, packing materials and so on, which are involved in the product manufacture [17].

Therefore, a description of the product (Table 2), a list of raw materials and other materials (Table 3), and a flow chart for the production of yogurt with honey products (Fig. 2) have been prepared for the analysis of threats and the development of a program for quality and safety management of the manufacture of yogurt with honey products based on the HACCP principles.

It should be noted that the technological process for manufacturing the yogurt with honey products differs from the conventional one by operations related to preprocessing of honey products and preparation of a fermentation mix on pasteurized skimmed milk (Fig. 2). In addition, to preserve the prebiotic properties of honey products, they are introduced at the stage of fermentation without additional heat treatment. The studies have shown that the microbiological purity of the finished product is stable until the safe level of acidity is reached [9]. 


\section{The Product Specification}

\begin{tabular}{|c|c|}
\hline Name of the product & Honey yoghurt \\
\hline Product properties & Titrated acidity $-90-120^{\circ} \mathrm{T}$ \\
\hline $\begin{array}{l}\text { which are important } \\
\text { for its safety }\end{array}$ & $\begin{array}{l}\text { Content of lactic acid bacteria: at } \\
\text { least, } 10^{9} \mathrm{cfu} / \mathrm{cm}^{3}\end{array}$ \\
\hline Use & Ready to use \\
\hline Potential customers & $\begin{array}{l}\text { All groups of population, except for } \\
\text { those who are sensitive to honey } \\
\text { products }\end{array}$ \\
\hline Packing & Sealed cups \\
\hline Shelf life & 7 days, at a temperature of $4 \pm 2{ }^{\circ} \mathrm{C}$ \\
\hline Place of sale & Retail network \\
\hline $\begin{array}{l}\text { Consumer instruc- } \\
\text { tions on the label }\end{array}$ & $\begin{array}{l}\text { Keep at a temperature of } 4 \pm 2{ }^{\circ} \mathrm{C} \text {, } \\
\text { shelf life expiry date must be spe- } \\
\text { cified }\end{array}$ \\
\hline Shipping conditions & $\begin{array}{l}\text { Cooled, transportation by special } \\
\text { vehicles }\end{array}$ \\
\hline
\end{tabular}

Raw Materials Used for Yoghurt Production

\begin{tabular}{|l|l|}
\hline \multicolumn{1}{|c|}{ Raw dairy material } & \multicolumn{1}{|c|}{ Unskimmed cow milk } \\
\hline $\begin{array}{l}\text { Biotechnological } \\
\text { material } \\
\text { Non-dairy material }\end{array}$ & $\begin{array}{l}\text { Bacterial preparation (S. thermophi- } \\
\text { lus, } \text { acidophilum, L. bulgaricus) } \\
\text { Sugar powder } \\
\text { Royal jelly } \\
\text { Pollen pellet } \\
\text { Honey } \\
\text { Packing materials }\end{array}$ \\
\hline
\end{tabular}

To identify the risk factors (biological, chemical, and physical) in the technology for manufacturing yogurt with honey products, it is necessary to sequentially answer the questions about each factor that could potentially be considered as dangerous at each stage of the product manufacture, as indicated in the decision-tree scheme [17, 67]. One of the first questions is, "Is it possible that the raw material bears any potential risk factor?" If the answer is "no", then this potentially dangerous factor in raw materials is not considered. The same is done in the case if the presence of hazardous factor in question in the production line is unlikely. If answer to the question "Is there an unacceptable level or is survival, steadiness or potential increase in the risk factor is possible at this stage?" is "no", then this potentially dangerous factor is excluded from the further analysis. However, if the answer is "yes," it is necessary to proceed to the next question, "Is any appropriate reduction in the risk factor at the next stage possible?" In the answer is affirmative, the potentially dangerous factor is not considered here, but the stage at which the corresponding reduction occurs is regarded as a critical point of control. If the answer to the above question is "no," then the "real" danger is considered to be identified, with control (preventive) measures established.

The hazard factors mentioned in the Law of Ukraine on the Basic Principles and Requirements for safety and Quality of Foodstuffs [4] and DSTU 4343:2004 Yoghurts. General Specifications are referred to the significant ones irrespective of the results of assessment.

The data obtained from the analysis of hazard factors are used to determine the following: + the severity of effects on the human health;

+ assessment of risks associated with identified hazards at different stages of the technological process;

+ points or stages where control leads to preventing threats or reducing them to an acceptable level, i.e. critical control points (CCPs).

The severity of effects is the magnitude of the hazard or severity of the consequences that may occur in the event of hazard. It indicates the type of effect induced by realization of the risk factor - from barely felt temporary discomfort to more serious reversible and irreversible consequences, including lethal complications [17].

Following the algorithms shown in Fig. 1, the probability of risk factor during the production of yogurt with honey products has been assessed. In addition, at this stage of research, further risk analysis is carried out for each potentially dangerous factor. The limit of permissible risk on the qualitative diagram with coordinates "Probability of hazard factor" and "Severity of effects" has been determined: if the point is on the borderline or above it, the factor is taken into account, whe- 


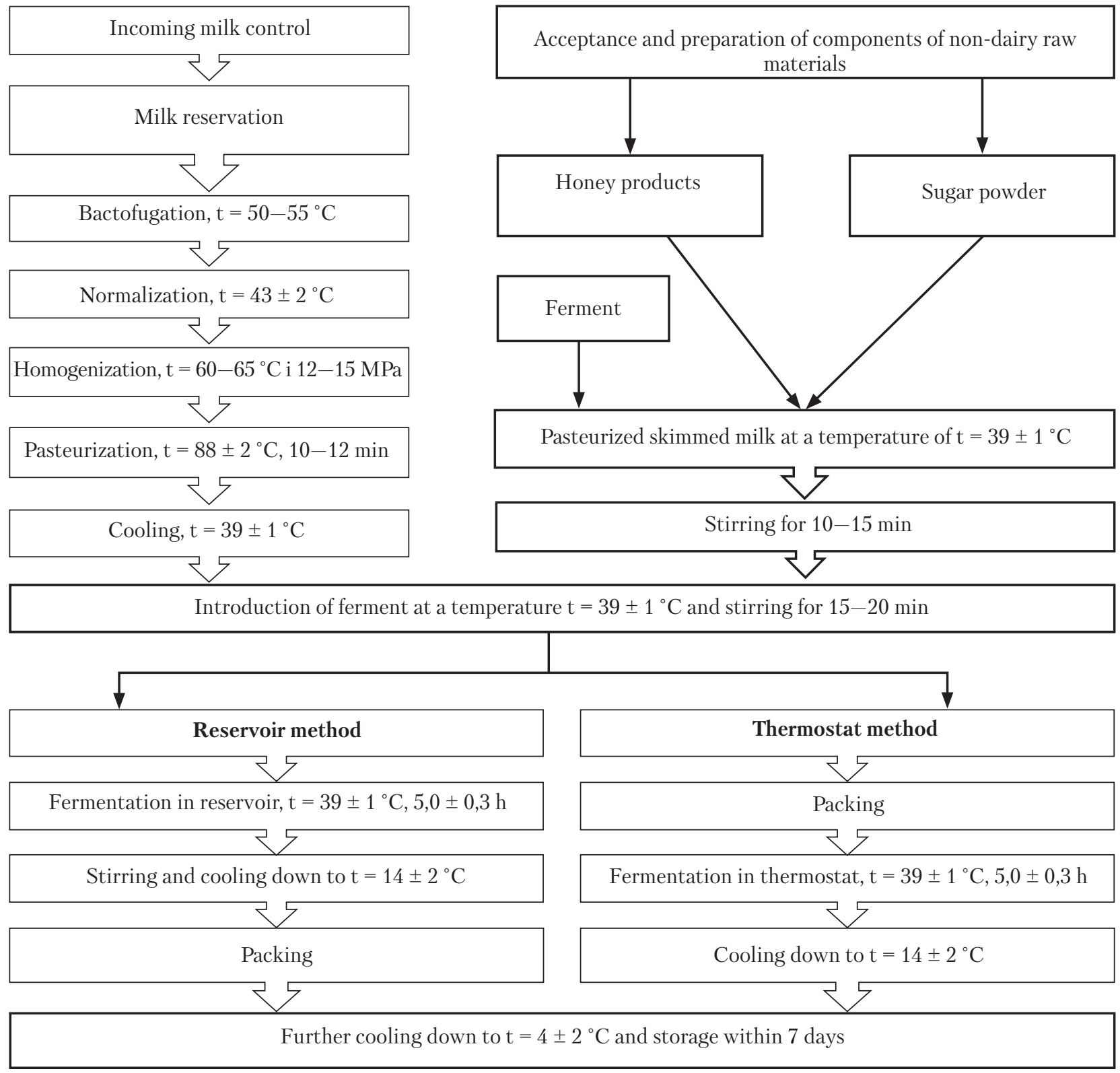

Fig. 2. Flow chart of technological process for manufacture of yoghurt with honey products

reas if the point is below, the factor is neglected $[17,80]$. For example, the E. coli group bacteria (ECGB), pathogenic microorganisms, in particular, Salmonella, Staphylococcus aureus, mold fungi, and yeasts are referred to the potentially dangerous biological factors. The probability of ECGB is assessed according to the algorithm (Fig. 1) and scores 3 points, while the severity of conse- quences scores 4 points. The obtained point is above the permissible risk level on the diagram. Consequently, the ECGB factor is taken into account during the yogurt production and its control. Thus, according to the analysis, the factors to be controlled are identified as follows: ECGB, pathogenic microorganisms (Salmonella, Staphylococcus aureus, molds and yeasts), mycotoxins 


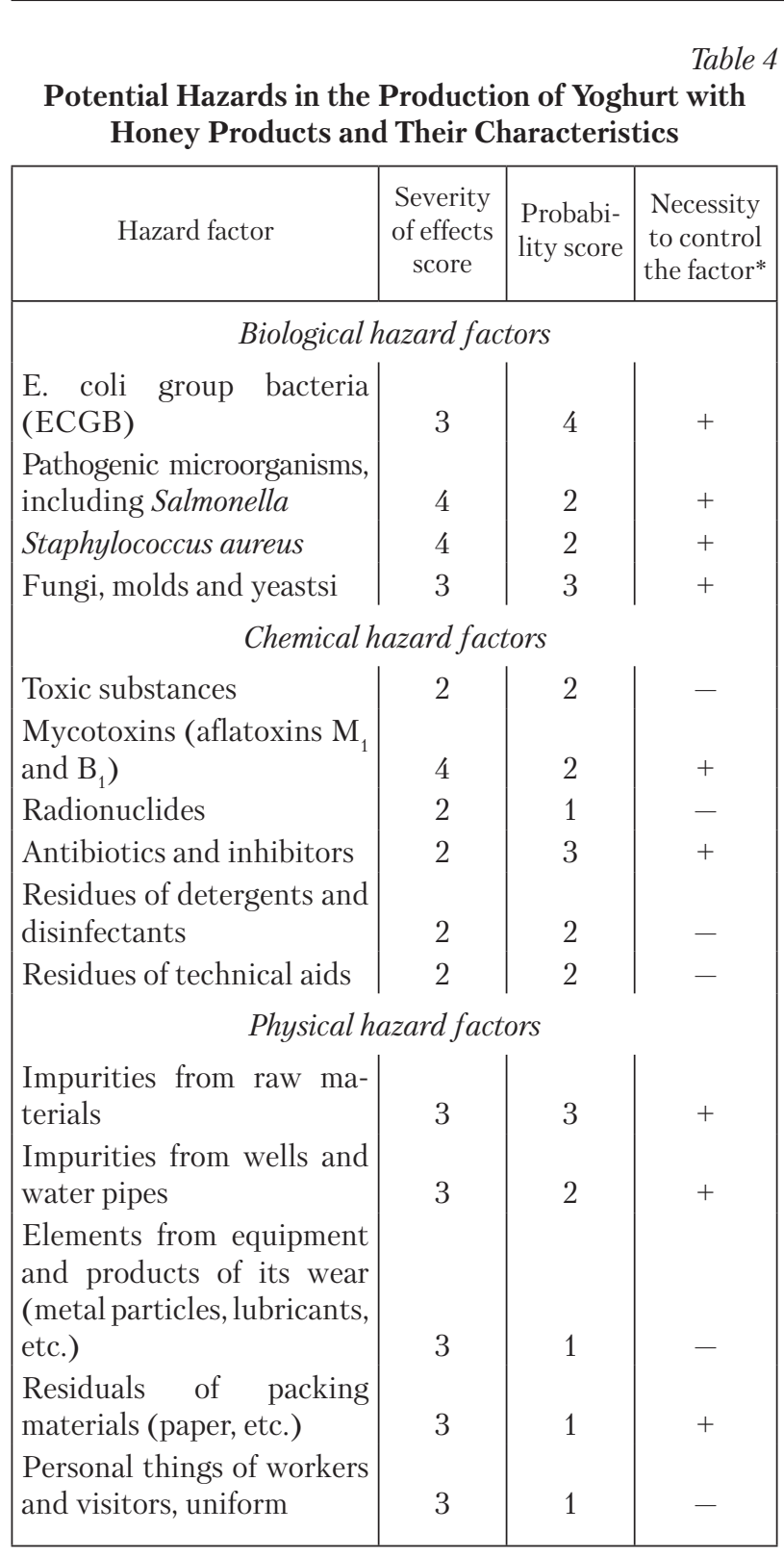

Note. ${ }^{*} \ll+»$ the factor is taken into account; «一» the factor is neglected

(in particular, aflatoxins $\mathrm{M}_{1}$ and $\mathrm{B}_{1}$ ), antibiotics and inhibitors coming from the raw materials, wells and water pipes, residues of packing materials, since their scores are higher than the permissible risk in the diagram.

As a result of the analytical study, the potential hazards related the production of yogurt with honey products have been listed (Table 4).
During the risk analysis, the points of the technological process, where control measures are to be implemented have been identified. Based on the analysis of these factors and the application of the decision-free scheme [17, 95] critical control points that significantly affect the quality and safety of yogurt with honey products have been determined. The critical control point is defined as the stage at which a control measure can be implemented and which is mandatory for the prevention of a threat to food safety, the elimination of such a threat or its reduction to an acceptable level.

To determine the CCP for raw materials and the process of producing yogurt with honey products, each question is answered at each stage where significant hazards are identified, and an algorithm for further actions is determined for each identified factor (Table 5).

As a result of the research, a rather significant amount of CCP has been identified. In the practice of the HACCP system development and operation, it is noted that such points should be no more than 8-10 [5]. In order to reduce the number of CCP, they have been combined according to the following rule: CCPs are combined if they are controlled by the same person and are related to the same operation (operation is the completed part of the technological process performed at one work station). The summarized results on the definition of critical control points during the production of yogurt with honey products are presented in Table 6.

The results of research on the identification of hazard factors and critical control points for the production of yogurt with honey products have been used to design a production flowchart for production by the reservoir method as the most economically advantageous, with critical control points (CCP) and corresponding quality indicators specified (Fig. 3).

Consequently, as a result of the analysis of hazard factors and risks for each of them, according to the composed list, the critical control points have been identified for the production of yogurt 
Decision Tree for Identifying the Critical Control Points for Raw Materials and Technological Process Operations Used in Manufacturing Yoghurt with Honey Products

\begin{tabular}{|c|c|c|c|}
\hline \multirow{2}{*}{ No. } & \multirow{2}{*}{ Question } & \multicolumn{2}{|c|}{ Actions depending on the answer } \\
\hline & & Yes & No \\
\hline 1 & $\begin{array}{l}\text { Can the raw material contain the identified } \\
\text { hazard factor at an unacceptable level? }\end{array}$ & $\begin{array}{l}\text { If there is uncertainty about the answer, } \\
\text { the answer is "yes" but further question } \\
\text { 3.2. is to be answered }\end{array}$ & $\begin{array}{l}\text { This raw material is not con- } \\
\text { sidered a CCP, go to the con- } \\
\text { sideration of the next raw } \\
\text { material }\end{array}$ \\
\hline 2 & $\begin{array}{l}\text { Will the processing, including the expected } \\
\text { use by the consumer, eliminate the hazard } \\
\text { factor or reduce its effect to an acceptable } \\
\text { level? }\end{array}$ & $\begin{array}{l}\text { The raw material is not critical, but the } \\
\text { stage of production process, where this } \\
\text { hazard is managed, has been defined as } \\
\text { CCP }\end{array}$ & $\begin{array}{l}\text { The raw material is consi- } \\
\text { dered a } \mathrm{CCP}\end{array}$ \\
\hline 3 & $\begin{array}{l}\text { Is formulation of a finished product im- } \\
\text { portant for preventing any increase in the } \\
\text { hazard factor to an unacceptable level? }\end{array}$ & $\begin{array}{l}\text { The relevant indicators of product or sta- } \\
\text { ge (for example, pH, water activity, tem- } \\
\text { perature, etc.) are considered as CCP }\end{array}$ & $\begin{array}{l}\text { None factor that does not lead } \\
\text { to change in the recipe is ta- } \\
\text { ken into account }\end{array}$ \\
\hline 4 & $\begin{array}{l}\text { Can the identified hazard factor reach or } \\
\text { increase to an unacceptable level at this } \\
\text { technological stage? }\end{array}$ & For any stage, go to question 3.5 & $\begin{array}{l}\text { For any stage, go to question } \\
3.6\end{array}$ \\
\hline 5 & $\begin{array}{l}\text { Will further processing, including the } \\
\text { expected use by the consumer, ensure } \\
\text { removal of or reduction in the hazard } \\
\text { factor to the permissible level? }\end{array}$ & $\begin{array}{l}\text { The stage of technological process is not } \\
\text { critical. Go to the next step, starting } \\
\text { with question } 3.3\end{array}$ & The analyzed stage is a CCP \\
\hline 6 & $\begin{array}{l}\text { Is this stage specifically designed to } \\
\text { eliminate or to reduce the hazard factor to } \\
\text { an acceptable level? }\end{array}$ & The analyzed stage is a CCP & $\begin{array}{l}\text { The analyzed state is not a } \\
\text { critical one. Go to the next sta- } \\
\text { ge starting with question } 3.3 \text {. }\end{array}$ \\
\hline
\end{tabular}

Critical Control Points of Production of Yoghurt with Honey Products

Table 6

\begin{tabular}{|c|c|}
\hline Stage of technological process (CCP) & Type and potential hazards \\
\hline Acceptance of raw milk (CCP 1) & $\begin{array}{l}\text { Biological: ECGB, mesophilic aerobic and facultative anaerobic microor- } \\
\text { ganisms (MAFAM), salmonella, tuberculosis, brucellosis, and somatic cells } \\
\text { Chemical: toxic substances, mycotoxins, antibiotics, pesticides, inhibitors, } \\
\text { radionuclides, and hormonal drugs }\end{array}$ \\
\hline $\begin{array}{l}\text { Acceptance of raw non-dairy materials } \\
(\mathrm{CCP} 2)\end{array}$ & $\begin{array}{l}\text { Biological: yeasts, molds, ECGB, MAFAM, salmonella, pathogenic staphy- } \\
\text { lococci. Chemical: toxic substances, mycotoxins, antibiotics, pesticides, ra- } \\
\text { dionuclides }\end{array}$ \\
\hline Milk cooling and reservations (CCP 3) & $\begin{array}{l}\text { Biological: ECGB, MAFAM, Listeria monocytogenes, salmonella, pathogenic } \\
\text { staphylococci }\end{array}$ \\
\hline Pasteurization ( CCP 4) & $\begin{array}{l}\text { Biological: ECGB, MAFAM, Listeria monocytogenes, salmonella, pathogenic } \\
\text { staphylococci, yeasts, molds, and fungi. Chemical: enterotoxins }\end{array}$ \\
\hline Fermentation (CCP 5) & $\begin{array}{l}\text { Biological: ECGB, salmonella, pathogenic staphylococci, S. aureus. Chemical } \\
\text { enterotoxins, residuals of detergents and disinfectants }\end{array}$ \\
\hline Packing (CCP 6) & $\begin{array}{l}\text { Biological: ECGB, MAFAM, yeasts, molds, and fungi. Chemical: Residuals of } \\
\text { detergents and disinfectants }\end{array}$ \\
\hline
\end{tabular}




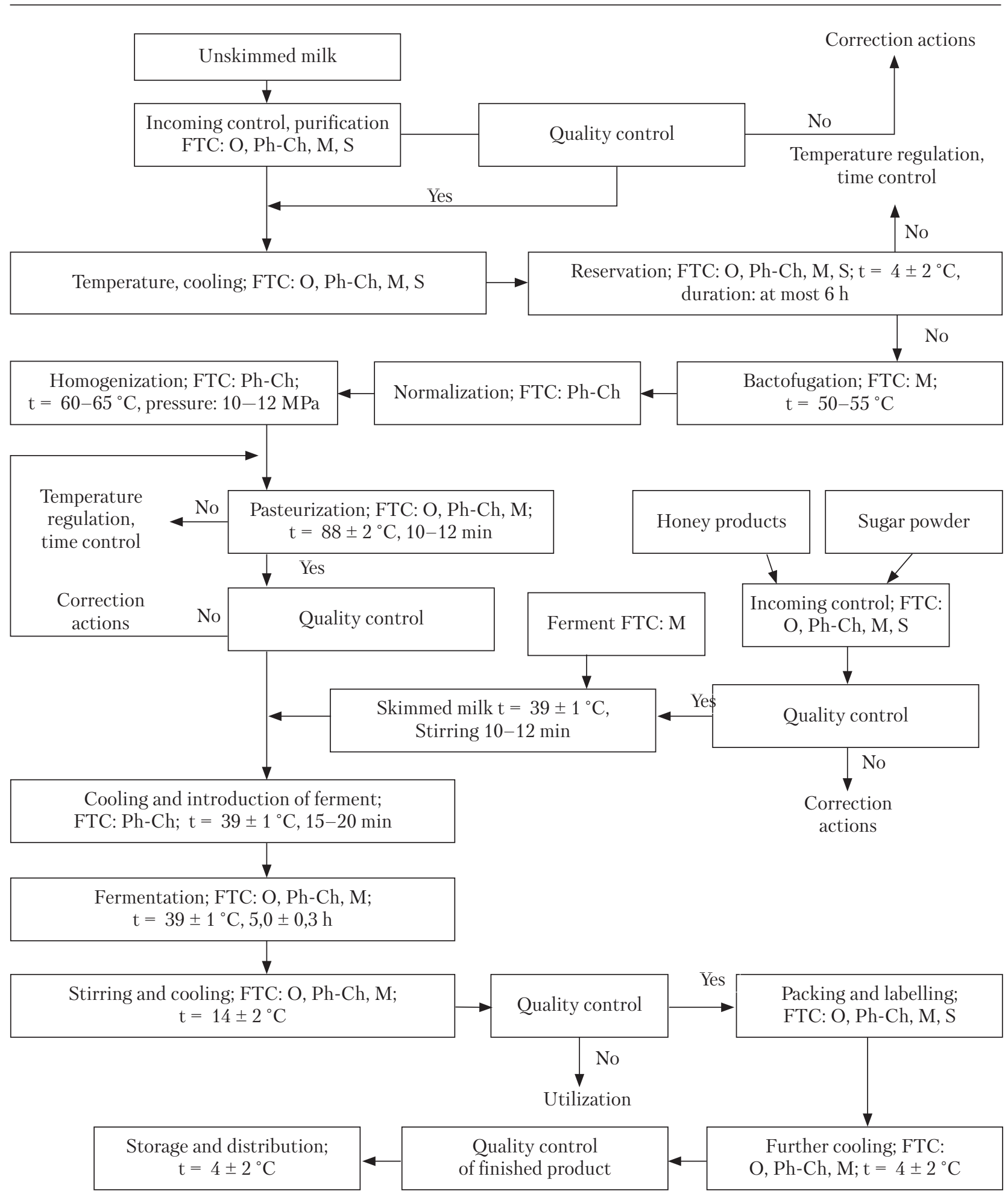

Fig. 3. Technological flow chart of manufacture of yoghurt with honey products by the reservoir method. Factors to be controlled: $\mathrm{O}$ - organoleptic; $\mathrm{Ph}-\mathrm{Ch}$ - physical and chemical; $\mathrm{M}$ - microbiological; S - safety 
Quality and Safety Indicators of Yoghurt with Honey Products Manufactured

Based on the Designed Production Flow Chart

\begin{tabular}{|c|c|c|c|}
\hline \multirow{2}{*}{ Indicator } & \multicolumn{2}{|c|}{ Value } & \multirow{2}{*}{ Control methods } \\
\hline & $\begin{array}{c}\text { According to DSTU } \\
4343: 2004^{*} \\
\end{array}$ & $\begin{array}{l}\text { In yoghurt with } \\
\text { honey products ** }\end{array}$ & \\
\hline Titrated acidity, ${ }^{\circ} \mathrm{T}$ & $80-140$ & $90-120$ & GOST 3624-92 \\
\hline $\begin{array}{l}\text { Number of lactic acid bacteria (S. ther- } \\
\text { mophilus, L. acidophilum, L. bulgaricus), } \\
\text { cfu per } 1 \mathrm{~cm}^{3}\end{array}$ & $10^{7}$ & $10^{9}$ & $\begin{array}{l}\text { GOST 10444.11-89, } \\
\text { DSTU IDF 117B:2003 }\end{array}$ \\
\hline Number of $S$. aureus, per $1 \mathrm{~cm}^{3}$ & NA & ND & GOST 30347-97 \\
\hline $\begin{array}{l}\text { Pathogenic microorganisms, in parti- } \\
\text { cular, Salmonella, bacteria per } 25 \mathrm{~cm}^{3}\end{array}$ & NA & ND & DSTU IDF 93A:2003 \\
\hline ECGB (coliform) per $0.1 \mathrm{~cm}^{3}$ & NA & ND & DSTU 7357:2013 \\
\hline Molds and fungi, $\mathrm{cfu} / \mathrm{cm}^{3}$ & $\leq 50$ & $\leq 50$ & GOST 10444.12-88 \\
\hline Yeasts, $\mathrm{cfu} / \mathrm{cm}^{3}$ & $\leq 50$ & $\leq 50$ & GOST 10444.12-88 \\
\hline \multicolumn{4}{|c|}{ Toxic elements, $\mathrm{mg} / \mathrm{kg}$} \\
\hline Lead & $\leq 0.100$ & $\mathrm{ND}(\leq 0.100)$ & GOST 26932-86 \\
\hline Cadmium & $\leq 0.030$ & $\mathrm{ND}(\leq 0.030)$ & GOST 26933-86 \\
\hline Mercury & $\leq 0.005$ & $\mathrm{ND}(\leq 0.005)$ & GOST 26927-86 \\
\hline Copper & $\leq 1.000$ & $\mathrm{ND}(\leq 1.000)$ & GOST 26931-86 \\
\hline Zinc & $\leq 5.000$ & $0.01 \pm 0.003$ & GOST 26934-86 \\
\hline Arsenic & $\leq 0.050$ & $\mathrm{ND} \leq 0.050$ & GOST 26930-86 \\
\hline \multicolumn{4}{|c|}{ Aflatoxins, $m g / k g$} \\
\hline $\mathrm{B}_{1}$ & $<0.001$ & $\mathrm{ND}(<0.001)$ & MB № 4082 \\
\hline $\mathrm{M}_{1}$ & $<0.0005$ & $\mathrm{ND}(<0.0005)$ & MB № 4082 \\
\hline
\end{tabular}

Note. *NA - not admitted; **ND - not detected.

with honey products. The proposed flow chart for the production of yogurt with honey products with the hazard factors and risks taken into account minimizes or completely reduces their occurrence, which fundamentally affects the quality and safety of the finished products (Table 7).

\section{Conclusions}

As a result of the research, innovative approaches, namely, the HACCP system principles for the technology of production of yogurt with honey products have been implemented to ensure the quality and safety of the yoghurt. For the first time, a unique comprehensive list of biological, chemical, and physical potential hazards has been proposed; critical control points have been identified for all stages of the production of yogurt with honey products. A flow chart for the production of yogurt with honey products by reservoir method using HACCP elements has been designed, and the quality and safety indicators of the finished product have been determined.

\section{REFERENCES}

1. Food safety risk communication resources. Joint Institute for Food Safety and Applied Nutrition. A joint project between the University of Maryland and the United States Food and Drug Administration. URL: http://www.foodriskclearinghouse.umd.edu/risk_comm_foodsafety.cfm. (Last accessed: 23.01.2018). 
2. Buchanan, R. L. (2010). Bridging Consumers' Right to Know and Food Safety Regulations Based on Risk Assessment. Risk Assessment of Foods. In C.-H. Lee (Ed.). KAST Press: Korea.

3. Byrd, D. M., Cothern, C. R. (2000). Introduction to risk analysis. ABS Consulting, Government Institutes Division, Rockville, Maryland.

4. Zakon Ukrainy № 774/97-VR «Pro vydavnychu spravu» vid 23 hrudnia 1997 r. [in Ukrainian].

5. Hazard analysis and critical control point (HACCP) system and guidelines for its application. (1996). Report of the $29^{\text {th }}$ session of the Codex Committee on food hygiene, Alinorm. 97/13A, Appendix II. Rome.

6. Mortimore, S., Wallace, C. (2013). HACCP - A practical approach second thirded. Chapman and Hall, London.

7. Ropkins, K., Beck, A. J. (2000). Evaluation of worldwide approaches to the use of HACCP to control food safety. Trends in Food Science \& Technology, 11(1), 10-21.

8. Working Principles for Risk Analysis Application in the Framework of the Codex Alimentarius. (2007). Codex Alimentarius Commission CAC/GL 62-2007.

9. Lomova, N. M., Snizhko, O. O., Ochkolias, O. M. (2017). Biotekhnolohiia kyslomolochnoho napoiu z kompleksom apiproduktiv. Kyiv [in Ukrainian].

10. Belov, Iu. P. (2005). Rozrobka ta vprovadzhennia systemy upravlinnia bezpechnistiu kharchovykh produktiv HACCP. Svit yakosti Ukrainy, 2, 42-45 [in Ukrainian].

11. Dyman, T. M., Mazur, T. H. (2011). Bezpeka prodovolchoi syrovyny i kharchovykh produktiv. Kyiv [in Ukrainian].

12. Yakubchak, O. M., Dyman, R. M., Oliinyk, L. V. (2005). Metodychni rekomendatsii shchodo vprovadzhennia systemy HACCP na molokopererobnykh pidpryiemstrakh. Kyiv [in Ukrainian].

13. Kassem, M., Salem, E., Ahwal, M., Saddik, M., Gomaa, F. (2002). Application of hazard analysis and critical control point system in the dairy industry. East. Medit. Health J., 8(1), 114-128.

14. Papademas, P., Bintsis, T. (2010). Food safety management systems (FSMS) in the dairy industry: a review. Intern. J. Dairy Technol., 63(4), 489-503. DOI: 10.1111/j.1471-0307.2010.00620.x.

15. Sandrou, D. K., Arvanitoyannis, I. S. (2000). Implementation of hazard analysis critical control point (HACCP) system to the dairy industry: current status and perspectives. Food Rev. Intern., 16(1), 77-111. DOI: 10/1081/FRI-100100283.

16. Ali, A. A., Randal, M. F. (2002). Implementation of HACCP to bulk condensed milk production line. Food Rev. Intern., 18(2-3), 177-190. DOI: 10/1081/FRI-120014687.

17. Systema HACCP. Dovidnyk. (2003). Lviv [in Ukrainian].

18. Gurinovich, G. V. (2011). Metodicheskie ukazanija k prakticheskim zanjatijam po discipline «Otraslevaja standartizacija i sertifikacija» dlja studentov special'nosti 260301 «Tehnologija mjasa i mjasnyh produktov» vseh form obuchenija. Kemerovo [in Russian].

Received 12.03.18

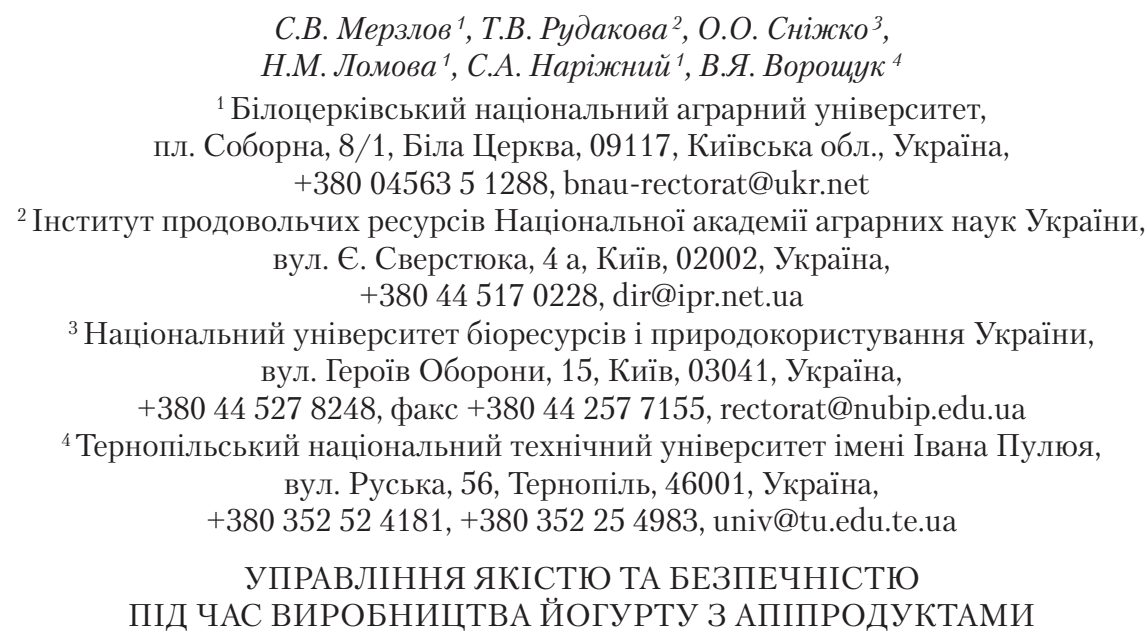

Вступ. Одним з інноваційних підходів до розроблення програм забезпечення якості й безпечності харчової продукції сьогодні є система на основі принципів НАССР (Hazard Analysis Critical Control Points - аналіз ризиків та критичні точки контролю). Система дозволяє запобігти виникненню небезпеки на ранніх стадіях виробництва харчової продукції. 
Проблематика. В Україні необхідно здійснювати особливий контроль показників якості та безпечності молочної продукції через низьку якість сировини та суттєву складність простеження ії̈ використання в процесі переробки, які, разом із відсутністю холодильної логістики та зберігання, суттєво скорочують термін придатності української молочної продукції порівняно з європейською.

Мета. Використання принципів НАССР під час розроблення нових видів молочних продуктів, зокрема, йогурту з апіпродуктами.

Матеріали й методи. Молочна, біотехнологічна та немолочна сировина, пакувальний матеріал, етапи технологічного процесу.

Результати. Проведено ідентифікацію всіх можливих чинників небезпеки, які можуть існувати в сировині, пакувальних матеріалах або під час застосування будь-якої технологічної операції, пов'язаної з виготовленням продукту. Здійснено аналіз ризиків за кожним потенційно небезпечним чинником під час виробництва йогурту з апіпродуктами та складено перелік потенційних небезпек відповідно до діаграми ризиків. Встановлено, що до групи біологічних потенційно чинників небезпеки належать бактерії групи кишкової палички, патогенні мікроорганізми, плісеневі гриби та дріжджі; до хімічних - токсичні елементи, радіонукліди, мікотоксини, антибіотики; до фізичних домішки, що надходять із сировиною, із водою, з технологічного обладнання, з пакувальних матеріалів. Визначено шість об'єднаних критичних точок контролю: приймання молочної і немолочної сировини; охолодження і резервування молока; пастеризація; сквашування; фасування.

Висновки. Розроблено технологічну блок-схему виробництва йогурту з апіпродуктами резервуарним способом з використанням елементів НАССР та визначено показники якості та безпечності готового продукту.

Ключові слова: йогурт, апіпродукти, якість, безпечність, технологія, ризик, небезпечний чинник, критичні точки контролю.

\author{
С.В. Мерзлов ${ }^{1}$, Т.В. Рудакова ${ }^{2}$, О.О. Снежко \\ Н.М. Ломова ${ }^{1}$, С.А. Нарижный ${ }^{1}$, В.Я. Ворощук ${ }^{4}$ \\ ${ }^{1}$ Белоцерковский национальный аграрный университет, \\ пл. Соборная, 8/1, Белая Церковь, 09117, Киевская обл., Украина, \\ +3800456351288, bnau-rectorat@ukr.net \\ ${ }^{2}$ Институт продовольственных ресурсов Национальной академии аграрных наук Украины, \\ ул. Е. Сверстюка, 4, Киев, 02002, Украина, \\ +380 44517 0228, dir@ipr.net.ua \\ ${ }^{3}$ Национальний университет биоресурсов и природопользования Украины, \\ ул. Героев Обороны, 15, Киев, 03041, Украина, \\ +38044527 8248, +380 44257 7155, rectorat@nubip.edu.ua \\ ${ }^{4}$ Тернопольский национальный технический университет имени Ивана Пулюя, \\ ул. Русская, 56, Тернополь, 46001, Украина, \\ +38035252 4181, +380352 25 4983, univ@tu.edu.te.ua

\section{УПРАВЛЕНИЕ КАЧЕСТВОМ И БЕЗОПАСНОСТЬЮ ПРИ ПРОИЗВОДСТВЕ ЙОГУРТА С АПИПРОДУКТАМИ}

Введение. Одним из инновационных подходов к разработке программ обеспечения качества и безопасности пищевой продукции является система на основе принципов НАССР (Hazard Analysis Critical Control Points - aнализ рисков и критические точки контроля). Система позволяет предотвратить возникновение опасности на ранних стадиях производства пищевой продукции.

Проблематика. В Украине необходимо осуществлять особый контроль показателей качества и безопасности молочной продукции из-за низкого качества сырья и существенную сложность прослеживаемости его использования в процессе переработки, которые, вместе с отсутствием холодильной логистики и хранения, существенно сокращают срок годности украинской молочной продукции по сравнению с европейской.

Цель. Использование принципов НАССР при разработке новых видов молочных продуктов, в частности, йогурта с апипродуктами.

Материалы и методы. Молочное, биотехнологическое и немолочное сырье, упаковочный материал, этапы технологического процесса.

Результаты. Проведена идентификация всех возможных опасных факторов, которые могут существовать в сырье, упаковочных материалах или при применении любой технологической операции, связанной с продуктом. Осуществлен анализ рисков по каждому потенциально опасному фактору при производстве йогурта с апипродуктами и 
составлен перечень потенциальных опасностей по диаграмме рисков. Установлено, что в группу биологических потенциально опасных факторов относятся бактерии группы кишечной палочки, патогенные микроорганизмы, плесневые грибы и дрожжи; к химическим - токсичные элементы, радионуклиды, микотоксины, антибиотики; к физическим - примеси, поступающие с сырьем и водой, из технологического оборудования и упаковочных материалов. Определены шесть объединенных критических точек контроля: прием молочного и немолочного видов сырья; охлаждение и резервирование молока; пастеризация; сквашивание; фасовка.

Выводы. Разработана технологическая блок-схема производства йогурта с апипродуктами резервуарным способом с использованием элементов НАССР и определены показатели качества и безопасности готового продукта.

Ключевые слова: йогурт, апипродукты, качество, безопасность, технология, риск, опасный фактор, критические точки контроля. 